easier time than those from elsewhere. Many of the former can obtain funding from organizations in their home countries or from other European community sources, and immigration issues are simplified.

For non-European citizens, however, the visa and immigration requirements and procedures are complex. Many institutions have little or no administrative structure to help foreign candidates navigate the complicated rules and regulations. In this regard, things are slowly improving in some institutions, such as the Pasteur Institute, but not in others, such as the Ecole Normale Supérieure, where candidates are left to their own devices.

The French government could greatly improve the pool of quality candidates available to its research organizations by developing new sources of funding available to all postdocs, and by simplifying the administrative procedures for foreigners wishing to train in France.

Andrew A. Munk

NewVentures Bioconsulting,

1015 Strauss Street, Suite 201, Brossard,

Québec J4X 1T2, Canada

\section{Planned law could put German research at risk}

Sir - The planned new university law in Germany (Hochschulrahmengesetz) is intended to make universities more competitive by abolishing the Habilitation requirement, and by creating new positions (Juniorprofessoren) to allow people to carry out independent research before attaining a tenured position (see News Feature, pages 768-770).

We fully support these aims, and firmly believe that the establishment of many more groups of independent young investigators is essential to making the German research system more flexible, attractive and productive. These groups could be modelled on the US system's assistant-professor grade, or on the independent research groups which are already established at several German universities and Max Planck institutes.

But the new law contains strict time constraints that severely undermine the competitiveness of German research, at least in the area of life sciences. We strongly believe this law must be changed before it goes through parliament.

The intention is that there will be no more than six years between the diploma (the examination required before beginning a $\mathrm{PhD}$ project) and the start of a junior professorship, which itself is limited to a maximum of six years. In a manner that may seem typically German, both time limits will be strictly enforced. After a transitional period, the completion of a period as Juniorprofessor will become the prerequisite for securing a regular, tenured position.

As a consequence, all $\mathrm{PhD}$ and postdoctoral work will have to be completed within only six years, which is much too short for many biomedical and other natural-science projects. It will become unrealistic to complete an innovative $\mathrm{PhD}$ project and then move to a new lab for postdoctoral research. Up to now, almost all postdocs working both in Germany and abroad have taken more than six years to complete their work. Yet under the new law, any scientist exceeding the six-year limit will be excluded from a post as Juniorprofessor. Far from luring German postdocs working in foreign countries back home, the new law will actually exacerbate the brain drain.

The time limit will effectively abolish the current postdoctoral system in Germany. The prerequisite for a post as Juniorprofessor will be an excellent $\mathrm{PhD}$ thesis, with no requirement for additional scientific work.

This regulation will increase the dependence of $\mathrm{PhD}$ students on their advisers, a dependency that may be even worse than that experienced by more senior scientists doing their Habilitation (which the new law is intended to mitigate) and will render everyone's subsequent academic career contingent on the initial stage of their scientific activity. Almost all Juniorprofessoren will lack the invaluable experience of having done research in more than one lab (within Germany or abroad) before starting their own group, and will be less inclined to change research topics.

In sum, the strict adherence to this sixyear rule will not only deprive German research labs of postdocs and exacerbate the brain drain, but will result in poorly qualified academics, lacking the valuable experience of having worked in different laboratories or on different subjects. Moreover, the emphasis on time, rather than quality, will encourage research projects that are safe and dull, rather than innovative yet risky.

More than 1,000 scientists (Professoren, group leaders, postdocs and students) support the views expressed here; their names and addresses are listed at www.zmnh.uni-hamburg.de/jentsch/ unterschriften.

Thomas Jentsch

Valentin Stein Zentrum für Molekulare Neurobiologie, University of Hamburg, Falkenried 94, D-20246 Hamburg, Germany
Hunger added an edge to Vincent's sharp wit

Sir - Glancing through old issues of Nature recently, I ran across the Millennium Essay "Sounds of Silence" by Robert C. Young (Nature 408, 141; 2000). The picture of Skull with a Burning Cigarette by Vincent van Gogh is striking. It is worth a comment, for van Gogh is arguably the artist whose paintings are mostly easily recognized. Skull with a Burning Cigarette scarcely fits our preconceived notions of van Gogh's work.

It was painted in the winter of 1885-1886 in Antwerp, and the artist was "mocking the procedure in drawing classes, where a skeleton invariably served as the basis of anatomical studies" (I. F. Walther and R. Metzger Vincent van Gogh, The Complete Paintings 217; Taschen; 1993).

The artist was objecting to the lifelessness of this procedure, the very opposite of what he wished to bring out in his paintings. The cigarette was added as he had just taken up smoking to deaden the hunger he felt so often. It has been suggested that this painting may, in a sense, be regarded as Van Gogh's first self-portrait.

Ajoy K. Baksi

Department of Geology and Geophysics,

Louisiana State University, E235 Howe Russell

Building, LSU Baton Rouge, Louisiana

70803-4101, USA

\section{Bacteria in biofilms are living an unnatural life}

Sir - Jean-Marc Ghigo in his interesting Letter (Nature 412, 442-445; 2001) states the oft-repeated canard that "most natural bacterial populations are found associated with environmental surfaces". This is not true.

Bacteria are the most numerous organisms in the biosphere. A quick look at a sample from the oceans, the largest habitat on Earth, would reveal individual bacterial cells (when stained for their DNA) scattered across the darkened field, like stars on a clear night.

Of course there are bacteria in biofilms, but in the biosphere these are the exception rather than the rule. Their more numerous free-living brethren may tell us more about why these bacteria live in such an unnatural state.

\section{David L. Kirchman}

College of Marine Studies,

University of Delaware, 700 Pilottown Road,

Lewes, Delaware 19958, USA 